\title{
Promoting a Sound Process for Teaching Awards Programs: Appropriate Work for Faculty Development Centers
}

\author{
Nancy Van Note Chism \\ Indiana University-Purdue University Indianapolis
}

Examination of a sample of teaching awards programs at colleges and universities in the United States shows that the selection process for most is not based on explicit criteria, evidence that matches the criteria, and announced standards for making judgments about the candidates. If teaching awards programs are to be effective on any level, whether serving as a symbol of institutional commitment, affirming good teachers, or inspiring others to teach well, the quality of their selection process must be credible. This chapter provides recommendations for how faculty development centers can help their institutions to craft a selection process that will enhance their existing programs or help shape new ones.

\section{INTRODUCTION}

Testled within a department structure or highly visible at the campus 1 level, teaching awards programs are part of the landscape at many colleges and universities. Some programs are carefully planned and thoughtfully enacted, but others are fraught with problems. As part of their organizational development mission to support and enhance the conditions within which teaching takes place, faculty development centers can make an important contribution by helping to ensure that teaching awards programs on their campuses are intentional and effective. 
This chapter reports findings from a study of teaching awards at colleges and universities in the United States and focuses on ways in which faculty development centers can help to improve awards programs on their campuses.

\section{Teaching Awards Literature}

The body of literature on teaching awards programs is small and often directed to purposes other than assessing the quality of the programs. For example, Lowman (1994) examined the nomination letters submitted for an awards program to arrive at characteristics commonly associated with excellent teaching, rather than to draw implications about the programs themselves. Often, the work that has been published on teaching awards is solely descriptive, with national or multicampus systems surveying the programs in operation within their purview or locale and summarizing the program features (Adams, 1977; Francis, 1976; McNaught \& Anwyl, 1993; Warren \& Plumb, 1999).

Some work has been done on the impact of awards programs (Chism \& Szabo, 1997; Francis, 1976; McNaught \& Anwyl, 1993), finding that awards programs reinforce and support good teaching and are important for publicly affirming the importance that the institution places on teaching but have little documented direct impact on teaching improvement through motivating other faculty to earn awards by teaching better.

Carusetta (2001) uses a framework proposed by Menges (1996) for evaluating the soundness of an awards program in assessing a program at her campus. Yet studies do not seem to exist that analyze the type of criteria, evidence, and standards in use by teaching awards programs.

The study addressed the following research questions:

- What criteria are teaching awards programs based on?

- In order to make judgments, what kinds of evidence do teaching awards programs collect?

- What standards do awards programs use to judge the evidence?

- Is there a match between the criteria and the evidence sought?

\section{Methods}

The study began with a survey of teaching awards programs that were described on the World Wide Web. The list of teaching centers on the web site of the Center for Teaching Excellence at the University of Kansas was used as 
part of a purposeful sampling strategy (Patton, 2002) that focuses on sources that are most likely to be information-rich, based on the reasoning that campuses with teaching centers were also more likely to have awards programs. If teaching awards programs were not described on the site of the teaching center, the academic affairs page of the institution or the campus web site were examined, using search engines. The decision rules for inclusion allowed only those programs for which complete information was available on the web (programs for which a packet of information had to be picked up or a telephone call made were excluded) and only those awards programs that were explicitly for teaching. This search produced usable information on 118 awards programs at 66 institutions.

In this first sample, two-year institutions and liberal arts colleges were underrepresented. This result may be due either to the fact that there are fewer awards programs at these institutions or that they use the World Wide Web less frequently to post information. To obtain more information from two-year and liberal arts colleges, a special email survey for information was sent to the chief academic officer at a random sample of 100 of these institutions, using lists from the Carnegie Classification of Institutions of Higher Education web site (http://www.carnegiefoundation.org/Classification/index.htm). This search produced usable information on 26 programs at 19 institutions, bringing the total sample to 144 programs at 85 institutions located in 33 states. Of these, 45 are classified as Doctoral/Research Universities-Extensive; 10 as Doctoral/Research Universities-Intensive; 13 as Master's Colleges and Universities I or II; 12 as Baccalaureate Colleges-General; and 5 as Community Colleges.

The information that was extracted from the program descriptions pertained to the criteria the programs list, the evidence that they seek, and the standards that they use in making the decisions on teaching award winners. Three coders worked with the data, differences were reconciled in meetings, and the codes and data excerpts were entered into a database for sorting and display.

\section{FindinGS}

In exploring the criteria, evidence, and standards and the match between these within a given awards program, the study relied on Angelo's (1996) definition of these factors of interest: "In the jargon of assessment and evaluation, the criteria of exemplary teaching will tell us what to look for; the indicators where; and the standards how" (p. 58).

No program in the sample explicitly listed standards for judging award winners. Perhaps judges in some programs use rating sheets that may indicate 
some level of excellence or procedures that call for them to rank candidates against each other using some scale that may or may not have reference points, but these were not publicly available.

With respect to criteria and evidence, more data were found. Table 20.1 displays the categories that were developed to accommodate the information on criteria.

TABLE 20.1

\section{Criteria Used in Teaching Awards Programs in Study}

\begin{tabular}{|c|c|c|}
\hline$\%$ & \# & Criteria Category Name Sample \\
\hline 52 & 73 & Global (excellent teacher) as the only criterion, or no criteria specified at all \\
\hline 38 & 55 & Specific characteristics of teaching performance listed \\
\hline 29 & 42 & Impact on student learning, promotion of learning outside classroom \\
\hline 27 & 39 & Student-centered approach, shows concern for growth and development \\
\hline 24 & 35 & Content knowledge, mastery of subject \\
\hline 20 & 29 & Leadership in promoting teaching on campus \\
\hline 16 & 23 & Range of seaching activities undertaken during career or current practice \\
\hline 16 & 23 & Curriculum development efforts, innovation in teaching \\
\hline 13 & 18 & Other \\
\hline 8 & 12 & Scholarship of teaching activities \\
\hline 6 & 8 & Professional development efforts \\
\hline 5 & 7 & Rigor of standards for student performance \\
\hline
\end{tabular}

Note: With the exceprion of the first factor, percentages reflect the use of multiple criteria and thus do not total $100 \%$.

Additional data that add to the information in the table include:

- When programs listed specific characteristics of teaching, these clustered into the following categories: communication skills, organization, high standards, clear goals, enthusiasm, strategies for student engagement, and focus on higher order thinking skills.

- Within the "Other" category are the following: 1) listed by six programs ( $4 \%$ of the sample) -appreciation for diversity; 2 ) mentioned by two programs-citizenship, openness to new ideas, resourcefulness, and interdisciplinary teaching; and 3) mentioned by only one program each- 
record of obtaining grants for teaching, participation in recruiting efforts, and visibility outside campus.

Table 20.2 displays findings on the evidence of teaching excellence specified by the 144 programs in the sample.

TABLE 20.2

Evidence Requested by Teaching Awards Programs in Study

\begin{tabular}{rlr}
\hline$\%$ & $\#$ Evidence Category Name & Sample Size: $\mathbf{n}=144$ \\
\hline 92133 & Letters \\
& - Nomination letrers $(29 \% ; 38 \%=$ with letrers of support) \\
& - Letters of support $(63 \% ; 62 \%=$ more than one kind) \\
& - from current or former students $(44 \%)$ \\
& - from peers/other faculty (41\%) \\
& - from administrators (deans, chairs) $(20 \%)$ \\
& - from unspecified writers (6\%)
\end{tabular}

6188 Student ratings of instruction

4970 Curriculum vitae

3753 Philosophy of teaching statement

$28 \quad 40$ List of teaching responsibilities

2536 Other

2029 Syllabi or other course materials

2029 Peer review summary or summary of classroom observation

1420 Teaching portfolio ( $3 \%=$ specific contents; $11 \%=$ unspecified contents)

1319 List of professional contributions in teaching (papers, presentations)

1217 List of contributions to promotion of teaching on campus

1015 List of previous rewards or recognitions for teaching

812 Unspecified "additional documentation," coupled with other evidence

812 Documentation of involvement with students outside classroom

710 Description of growth in teaching and self-learning over time

710 List of professional development activities in teaching

69 Descriptions of innovations in teaching

57 No evidence specified at all (send "documentation")

Note: Percentages reflect the use of multiple types of evidence and thus do not total $100 \%$. 
With respect to the letter as the most popular form of evidence, some additional data include:

- $33 \%$ of the programs rely on nomination letters or letters of support alone and require no other source of evidence.

- $41 \%$ of the programs that ask for letters call for multiple letters of support.

- In $74 \%$ of the cases calling for letters of nomination or support, the letter writers are not given any instructions about what their letter should address.

- Only one program asks that the letter writers have specific evidence (the candidate's teaching portfolio) before them when they write their letters.

- Four of the 144 programs state that the letter writer should have firsthand knowledge of the candidate's teaching, one of which requires that the person have team-taught, been part of a teaching circle, or participated in curriculum development with the candidate.

The "No evidence specified" category, coded in the case of seven programs, includes directions to nominators or candidates to send appropriate documentation, with no more specific details on this. In 12 cases, requests were made for an appendix or "supporting documentation" to be submitted in addition to other evidence.

Evidence requirements that were not frequently mentioned across the sample were coded as "Other." These included grade distribution charts, votes of students, a list of favorite web sites, a record of outreach teaching to local high schools, videotapes, and telephone interviews with the committee.

One additional observation that can be made about the findings in general is that several awards programs are constructed around a two-stage process, whereby votes or letters are solicited during the first phase, and then selected candidates are invited to submit additional materials during the second phase.

\section{Discussion}

The most striking observation on the criteria employed by teaching awards programs at U.S. colleges and universities is that for over half of the programs in this study's sample, no criteria more specific than "teaching excellence" are mentioned. The most common source of evidence is the letter, for which the writer is typically not given any instruction on what to address nor has any standard information about the candidate from which to write the letter. 
Clearly, most teaching awards programs operate under the assumption that we do not need to be explicit about what we are awarding and that we know it when we see it.

Moreover, by failing to match criteria to evidence, these programs are collecting evidence that may not address their criteria (when they have them) or give them irrelevant materials. The reliance by most awards programs on secondary forms of evidence (such as appraisals by others) rather than primary evidence (such as course materials, teaching philosophy statements, or samples of student work) indicates reluctance on the part of many committees to actually engage the evidence firsthand.

The process of having two phases to an awards competition is another issue that influences the process in potentially undesirable ways. While it is advantageous to screen candidates, both for the efficiency of the selection process and the faculty who are preparing nomination materials, it is no less important at this stage to do so in a systematic way, since the results of the first phase necessarily influence the final selection.

Although the findings from this study indicate a range of problems inherent in the design of awards programs generally, it must also be pointed out that many programs have exemplary qualities, some in identifying criteria and aligning these with campus statements on teaching excellence, others in the careful specification of evidence. These components can be held forth as models for good practice. (See Appendix 20.1 for some examples.)

When teaching awards are unsystematic, however, several possible reasons may exist. First, the teaching awards may be more symbolic than substantive. In other words, as long as some people are chosen and elevated, the awards program has served its goal by making support for teaching visible. Second, awards program committees may feel that they have to take shortcuts in making judgments since it would be too time-consuming to do a thorough job. Many awards programs are low-stakes activities that involve a plaque or small monetary award. So investing a lot of time in making the awards decision might not seem worthwhile to the committee. Third, not much thought may go into the development of awards programs, or fourth, their framers may not have much knowledge of teaching and learning.

The mixture of findings in the literature on the impacts of teaching awards programs noted at the start of this chapter might cause institutions to avoid implementing or continuing such programs. However, when a program is pursued as a desirable activity compatible with the goals of a given institution, conceptualizing this award to meet its purpose seems important. Helping with this task lies well within the province and expertise of faculty development centers. 


\section{RECOMMENDATIONS}

Potential ways in which faculty development centers can help reframe or develop teaching awards programs on their campuses include the following:

- Promoting reflection about the purposes of the award

- Fostering the identification of criteria for teaching awards

- Helping programs to identify categories of evidence to be submitted by candidates

- Assisting with identifying standards

\section{Promoting Reflection About the Purposes of the Award}

If the purpose of a program is largely symbolic, that is, the award is being created to show that the campus values teaching, the need for a systematic process is no less important than if the program is to address the goals of affirming individuals or inspiring others (Menges, 1996; Middleton, 1987). An awards program that has vague criteria, relies on little evidence, and has no standards will quickly be revealed as meaningless and consequently will undermine its symbolic value. It will be labeled a "popularity contest," and rightly so. If the purpose is to affirm individuals, it is important to communicate what values are being promoted and to set in place mechanisms for identifying which faculty exemplify these values. If the purpose is to inspire others, the open communication of the values and standards is important for outlining the goals that faculty will have to pursue in their quest for excellence as well as what evidence they should be collecting to support their case.

\section{Fostering the Identification of Criteria for Teaching Awards}

This task is central to faculty appraisal activities on all campuses. It is at the heart of peer review systems, promotion and tenure or annual review procedures, student ratings instrument construction, and even faculty development planning. If a campus has not identified those characteristics of teaching that are important in its context, all of these activities are without an anchor. While a beginning point is the literature on teaching effectiveness (summarized in Chism, 2004), which faculty development centers can bring to the table, campus-specific goals will infuence the articulation of which characteristics are most salient in the particular context. For example, on campuses where remote learners are a big part of the population, excellence in the use of instructional technologies needed for distance education may be important, whereas at a small, residential school, in-person accessibility through office hours or 
faculty participation in student events may be more important. The work of listing these criteria for teaching excellence is not easy, yet it is a fascinating discussion that can be developmental in itself for all those who participate. While even on a small campus, disciplinary differences exist in the ways in which teaching is approached, the identification of a broad list of characteristics is not impossible and is essential to all faculty appraisal activities (some examples can be found in Appendix A).

\section{Helping Programs to Identify Categories of Evidence to Be Submitted by Candidates}

The discussion will revolve around ways to gather good information on whether the teaching of a given candidate exhibits the criteria and to what degree. In much of the evaluation literature (e.g., Centra, 1993), charts exist that indicate where one might find evidence for judging certain aspects of teaching. Another example from the general literature is McAlpine and Harris (2002), who list seven areas of teaching, sample criteria for performance, and evidence that may indicate acceptable, good/excellent, and exemplary performance. Constructing such a grid around the criteria that have been identified for the campus and having those framing the award think logically about what forms of evidence would inform them about each is a task that a faculty development center can facilitate. Such an exercise is akin to the normal way in which developers help faculty to develop student assessment plans. If the use of active learning methods is a criterion, for example, would the syllabus be a good indicator? Would sample course materials? Would a student rating item on active learning? All of the above?

Since most awards programs rely on letters of nomination or support, one simple thing that faculty development centers can do to enhance the value of these as evidence is to direct the letter writers to the set of criteria for the award. If even more standardization is desired, the request for letters can be replaced by the use of forms, either in print or electronic, that ask people to speak to each criterion and give them space for comment, along with a space at the end for additional comments that the nominator/supporter wishes to make. Asking letter writers to review documents or have some other source of direct knowledge of the candidate's performance can help to make the letters more substantive. For example, in one competition, candidates must prepare a teaching portfolio, which is then reviewed by those who are to write letters (see FACET example in Appendix 20.1 for details).

It is important in the specification of evidence for teaching awards to adhere to the same recommendations on good evaluation of teaching that are 
promoted throughout the literature on faculty evaluation by calling for evidence to be collected from multiple sources, using multiple methods, over multiple points in time (Braskamp \& Ory, 1994; Centra, 1993).

\section{Assisting With Identifying Standards}

Perhaps the most problematical part of the task is the development of standards. Because no awards program in the sample studied listed standards, those developing programs must find it hard to define and articulate levels of accomplishment. An example of the articulation of standards, in addition to the McAlpine and Harris (2002) paper mentioned above, is a guide to evaluating philosophy of teaching statements (Schonwetter, Sokal, Friesen, \& Taylor, 2002) that lists categories of superior, average, and poor. At first, it may be possible to develop tentative standards, such as the following for the example of the scholarship in teaching.

- Acceptable: Participation in campus events on teaching, presence of reflective comments and references to the literature on teaching and learning in philosophy of teaching statement

- Good/excellent: Above, plus participation in inquiry on teaching, presentation of teaching work at conferences or workshops

- Exemplary: Above, plus at least one publication on the scholarship of reaching and learning

Both sources above use other schemes, which serve as good models.

These standards may then be tested during a first year of use and refined, progressively arriving at the articulation of standards for excellence that may be useful for other faculty appraisal purposes in addition to the awards program. Making these standards explicit is similar to using grading rubrics to provide students with guidelines and goals. They shape behaviors as well as enable constructive feedback and consistent judgments. Articulation of standards early on can also be useful in reframing the initial stage of two-stage awards processes by deterring frivolous nominations as well as providing a straightforward screening mechanism.

\section{Stimulating Continual Inquiry as the Program Unfolds}

New circumstances, changing values in teaching, and new actors all will necessarily influence the effectiveness of teaching awards programs. In kecping with the reflective practice values promoted by faculty developers, centers can help existing awards programs to develop a system for examining their process 
at key intervals. Whether this be scholarship on the impact of the program or formative evaluation for ongoing improvement, this activity is important to the health of the program. Menges (1996) offers a useful list of questions for assessing teaching awards programs that may be used for self-assessment (see Appendix 20.2).

\section{SUMmaRY}

Teaching awards programs that are not well conceived and implemented fall into the category of those unexamined practices that ultimately undermine the work of teaching development. Helping institutions to revise or develop new programs is thus an important arena for faculty developers. The issues that are involved are ideal for the convening of a community of inquiry, an effective organizational development tool (Wenger, 1998; Wenger, McDermott, \& Snyder, 2002). Such communities begin with a problem relevant to their work and engage in dialogue and information collection to explore the issue and generate alternative courses of action. The role of the developer is to serve as a resource, helping the faculty to locate insightful work that bears on the issue, as well as to facilitate the discussion by helping to schedule meetings, communicate between meetings, and keep the discussion on track and inclusive during meetings.

Ultimately, the work of helping faculty to identify criteria, evidence, and standards for teaching awards can be useful to the campus in additional ways. These criteria and evidence may inform annual review or promotion and tenure procedures. They may be used by faculty in formulating their teaching development plans. If a standard set of criteria and evidence is judged to be useful for several purposes, it might form the basis for an electronic teaching portfolio that faculty can use in the storage of information on their teaching. Such a portfolio would enable quick retrieval of information in a standard format for several purposes, thus enhancing the efficiency of these processes.

The developer who wishes to foster a community of inquiry on teaching awards is not starting from scratch. As indicated above, many lists of the characteristics of teaching effectiveness are in the literature, as are suggestions in the evaluation literature on evidence that speaks to certain areas of teaching. It is also likely that somewhere in the documentation of teaching appraisal processes on one's campus, there is language that speaks to criteria, evidence, or standards that can be used as a start. Many campuses have listed these on the World Wide Web. These lists can be retrieved and used as discussion starters (see Appendix 20.1 for examples). 
The work of faculty development thrives within a climate where the many dimensions of excellence in teaching are appreciated and articulated, where excellence in teaching is pursued and rewarded, and where unexamined practices influencing growth and recognition of teaching are unearthed and critiqued. Engaging in the exploration of teaching awards programs is thus an important faculty development task, for the organization as well as for the individuals involved.

\section{NoTE}

The author wishes to acknowledge the help of Brian King and Melody Coryell in the data collection and coding process.

\section{REFERENCES}

Adams, C. C. (1977). Faculty awards programs: Campus-based and systemwide. Long Beach, CA: California State University and Colleges, Center for Professional Development. (ERIC Document Reproduction Service No. ED136725)

Angelo, T. A. (1996). Relating exemplary teaching to student learning. In M. D. Svinicki \& R. J. Menges (Eds.), New directions in teaching and learning: No. 65. Honoring exemplary teaching (pp. 57-64). San Francisco, CA: Jossey-Bass.

Braskamp, L. A., \& Ory, J. C. (1994). Assessing faculty work: Enhancing individual and instirutional performance. San Francisco, CA: Jossey-Bass.

Carusetta, E. (2001). Evaluating teaching through teaching awards. In C. Knapper $8<$ P. Cranton (Eds.), New directions in teaching and learning: No. 88. Fresh approaches to the evaluation of teaching (pp. 31-40). San Francisco, CA: Jossey-Bass.

Centra, J. A. (1993). Reflective faculty evaluation: Enhancing teaching and determining faculty effectiveness. San Francisco, CA: Josscy-Bass.

Chism, N. V. N. (2004). Characteristics of effective teaching in bigher education: Between definitional despair and certainty. Manuscript submitted for publication.

Chism, N. V. N., \& Szabo, B. (1997). Teaching awards: The problem of assessing their impact. In D. DeZure \& M. Kaplan (Eds.), To improve the academy: Vol. 16. Resources for faculty instructional, and organizational development (pp. 181-200). Stillwater, OK: New Forums Press.

Francis, J. B. (1976). An evaluation of programs to recognize and reward seaching excellence. Buffalo, NY: State University of New York at Buffalo, Department of Higher Education. (ERIC Document Reproduction Service No. ED156723) 
Lowman, J. (1994). Professors as performers and motivators. College Teaching, 42, 137-141.

McAlpine, L., \& Harris, R. (2002). Evaluating reaching effectiveness and teaching improvement: $A$ language for institutional policies and academic development practices. International Journal of Academic Development, $7(1), 7-17$.

McNaught, C., \& Anwyl, J. (1993). Awards for teaching at Australian universities (Centre for the Study of Higher Education Research Working Papers No. 93.1). Victoria, Australia: University of Melbourne. (ERIC Document Reproduction Service No. ED368291)

Menges, R. J. (1996). Awards to individuals. In M. D. Svinicki \& R. J. Menges (Eds.), New directions in teaching and learning: No. 65. Honoring exemplary teaching (pp. 3-9). San Francisco, CA: Jossey-Bass.

Middleton, A. (1987, October). Teaching awards and tokenism. Teaching Professor, $1(8), 3-4$.

Patton, M. Q. (2002). Qualitative evaluation and research methods (3rd ed.). Thousand Oaks, CA: Sage.

Schonwetter, D. T., Sokal, L., Friesen, M., \& Taylor, K. L. (2002). Teaching philosophies reconsidered: A conceptual model for the development and evaluation of teaching philosophy statements. International Journal of Academic Development. 71), 83-97.

Warren, R., \& Plumb, E. (1999). Survey of distinguished teacher award schemes in higher education. Journal of Further and Higher Education, 23(2), 245-255.

Wenger, E. (1998). Communities of practice: Learning, meaning and identity. New York, NY: Cambridge University Press.

Wenger, E., McDermott, R., \& Snyder, W. M. (2002). Cultivating communities of practice: $A$ guide to managing knowledge. Boston, MA: Harvard Business School Press. 


\section{APPENDIX 20.1}

\section{A Selection of Exemplary Awards Programs}

Distinguished Faculty Teaching Award, California State University-Long Beach http://www.csulb.edu/-senate/Awards/DFTA/guidelinedfta.html

Criteria are defined in some detail and evidence includes secondary evaluations, but also syllabi, course materials, and reflective statement from the candidate.

Distinguished Teaching Award, University of California-Berkeley http://teaching.berkeley.edu/dta-guidelines.html

This award uses criteria that have been defined in the handbook for faculty as indicators of teaching excellence. A two-stage judging process exists. Required evidence for the first stage includes general information and evaluations from others and the second stage evidence entails statements of goals and experience as well as supporting course materials along with the other evidence.

Bender Teaching Awards, The George Washington University http://www.cidd.gwu.edu/excellence/bender.html

This program is an example of an award with clear criteria, some of which indicate how the criteria might be measured. The award requests teaching materials as well as letters, student evaluations, and other secondary measures.

Teaching Recognition Program, University of Illinois-Chicago http://www.uic.edu/depts/oaa/cet/TRP/index.heml

This award is very thorough in its discussion of both criteria and evidence. It refers candidates to a table developed by the Teaching Documentation Task Force that matches criteria to evidence in the evaluation of teaching.

Alumni Teaching Excellence and Board of Governors' Teaching Excellence Awards, University of North Carolina-Greensboro hetp://www.uncg.edu/tlc/atcacri.hem 
These awards both follow the same two-stage process. Criteria are spelled out clearly. A statement of teaching philosophy, goals, and methods as well as a teaching curriculum vitae are required during the first phase, and teaching portfolio during the second. The awards information provides an itemized list of what the portfolio should contain, which includes reflective statements as well as course materials and materials submitted by orhers.

Faculty Colloquium on Excellence in Teaching (FACET) Award, Indiana University

http://www.iupui.edu/-facet/03callweb3.htm

Candidates seeking membership to this teaching academy must complete a course portfolio, which is then reviewed by two peers. The guidelines speak to the importance of documenting teaching and call for reflective and full information. FACET uses a web-based form that prompts both candidates and peer reviewers to provide consistent information. 


\section{Appendix 20.2}

\section{Questions to Ask in Evaluating Teaching Award Programs}

From: Menges, R. J. (1996). Awards to individuals. In M. D. Svinicki \& R. J. Menges (Eds.), New directions in teaching and learning: No. 65. Honoring exemplary teaching (pp. 3-9). San Francisco, CA: Jossey-Bass. This material is used by permission of John Wiley \& Sons, Inc.

\section{Selection Validity Test}

The selection validity test asks to what extent the program does what it claims to do, that is, how well does it select from all the eligible teachers those who are truly exemplary. This test has two dimensions: accuracy and representativeness.

\section{Accurate selection}

Does the program reflect core values of the institution? For example, if setting high expectations for students is a core value, how is that value reflected in the program? If collaboration among faculty is valued at the institution, how is that value reconciled with a program that is inherently competitive?

Are selection criteria and procedures generally known by faculty? Is there consensus that they are "correct"?

Does selection utilize information of various types (both qualitative and quantitative) and information from several sources?

Are nominees considered not only in light of their past accomplishments but also in light of their teaching plans for the future?

How confident are those who make selections that recipients are demonstrably superior in terms of program criteria?

\section{Representativeness}

Do recipients fairly represent the variety of fields (disciplines and other programs of study) and instructional situations (seminar, lab, studio, clinic, lecture hall)?

Do recipients fairly represent the variety of instructional activities that faculty perform (both in class and out)?

Is the program free of gender and ethnic biases?

\section{Faculty Motivation Test}

A successful program to honor exemplary teaching will energize faculty, making them more attentive to their teaching and its impact. This should be apparent to students and colleagues, and it should be evident more generally in the climate of the institution. The first four questions below deal with ways 
that programs can ensure the incentive value of awards, and the remainder suggest evidence for increased faculty motivation.

\section{Ensuring Incentive Value}

Are awards sufficiently numerous to encourage qualified faculty to apply?

Can each recipient choose from a menu of awards what is personally most valuable?

Is the value of the award at least as great as the effort required to obtain it?

Do unsuccessful applicants receive information about how their applications could be strengthened?

\section{Evidence of Increasing Motivation}

Are application rates increasing? Is there clamor for expansion of the program?

Do recipients report positive experiences in the wake of receiving the award?

Is there evidence that informal conversation about teaching has increased and become more thoughtful?

Do more teaching-related items appear on agendas of departmental and commitree meetings?

Are instructional experiments and innovations more common?

Have student course and teacher evaluations become more positive?

\section{Test of Public Perceptions}

This test seeks evidence that external audiences have increased appreciation that teaching is valued and rewarded at the institution and that the quality of teaching and learning has improved.

Is media coverage about teaching more extensive and more positive?

When prospective students and their parents ask about teaching and programs of study, are their questions answered more readily?

When legislators ask about such matters as faculty workload, are their questions better informed?

Has external funding for the support of instructional innovation increased? 


\section{Bibliography}

Adams, C. C. (1977). Faculty awards programs: Campus-based and systemwide. Long Beach, CA: California State University and Colleges, Center for Professional Development. (ERIC Document Reproduction Service No. ED136725)

Adso, J. (2002, February 27). Figuring out what counts in the tenure game. Chronicle of Higher Education Career Network. Retrieved November 9, 2002, from http://chronicle.com/jobs/2002/02/2002022701 c.htm

Aguirre, A., Jr. (2000). Women and minority faculty in the academic workplace: Recruitment, retention and academic culture (ASHE-ERIC Higher Education Report, 27[6]). San Francisco, CA: Jossey-Bass.

Aiken, S., Anderson, K., Dinnerstein, M., Lensink, J. N., \& MacCorquodale, P. (1988). Changing our minds: The problematics of curriculum integration. In $S$. H. Aiken (Ed.), Changing our minds: feminist transformations of knowledge (pp. 134-163). Albany, NY: State University of New York Press.

Allen, M. J., McMillin, J. D., Noel, R. C., \& Rienzi, B. M. (1999, June). Outcomes assessment for program improvement. Paper presented at the California State University Teacher-Scholar Summer Conference, San Jose, CA.

Atemeyer, B. (1988). Enemies of freedom: Understanding right-wing authoritarianism. San Francisco, CA: Jossey-Bass.

American Association of State Colleges and Universities. (1999). Facing change: Building the faculty of the future. Washington, DC: Author.

American Association for Higher Education. (1997). 9 principles of good practice for assessing student kearning. Washington, DC: Author. Retrieved May 6, 2004, from http://www.aahe.org/assessment/principl.htm

American Association for Higher Education. (2003). Resources for inquiry and action: The learning-centered institution. Inquiry and Action, I. Retrieved December 11, 2003, from http://www.aahe.org/pubs/lASpring2003.pdf

American Federation of Teachers. (2002). Standards of good practice in the employment of part-simeladjunct faculty: Faimess and equity. Washington, DC: Author. Retrieved May 9, 2004, from http://www.aft.org/higher_ed/images/Booklet.pdf 
Angelo, T. A. (1996). Relating exemplary teaching to student learning. In M. D. Svinicki \& R. J. Menges (Eds.), New directions in teaching and learning: No. 65. Honoring exemplary teaching (pp. 57-64). San Francisco, CA: Jossey-Bass.

Angelo, T. A., \& Cross, P. K. (1993). Classroom assessment techniques: $A$ handbook for college teachers (2nd ed.). San Francisco, CA: Jossey-Bass.

Antonio, A. L. (2002). Faculty of color reconsidered. Retaining scholars for the future. Journal of Higher Education, 73(5), 582-602.

Approaches to staff development for part-time faculty. (1986, July 1). ERIC Digest. (ERIC Document Reproduction Service No. ED270180). Retrieved May 9, 2004, from http://www.ericfacility.net/databases/ERIC_Digests/ed270180.html

Argyris, C., \& Schon, D. (1978). Organizational learning: A theory of action perspective. Reading, MA: Addison-Wesley.

Arnold, G., \& Civian, J. T. (1997, July/August). The ecology of general education reform. Change, 29(4), 19-23.

Association of American Colleges. (1985). Integrity in the college curriculum: A report to the academic community. Washington, DC: Author.

Association of American Colleges and Universities. (2002). Greater expectations: $A$ new vision for learning as a nation goes to college. Washington, DC: Author. Retrieved June 2, 2003, from http://www.greaterexpectations.org

Association of American Universities. (1998). Committee on graduate education: Report and recommendations. Washington, DC: Author. Retrieved August 13, 2002, from http://www.aau.edu/reports/GradEdRpt.heml

Astin, A. W. (1984, July). Student involvement: A developmental theory for higher education. Journal of College Student Personnel, 25, 297-308.

Astin, A. W. (1993). What matters in college? Four critical years revisited San Francisco, CA: Jossey-Bass.

Astin, H. S., Antonio, L. S., Cress, C. M., \& Astin, A. W. (1997). Race and ethnicity in the American professoriate, 1995-96. Los Angeles, CA: Higher Education Research Institute, University of California Los Angles.

Astin, H. S., \& Cress, C. M. (1998). A national profile of women faculty in research universities. Invitational Conference at Harvard University, Committee for Gender Equity, Cambridge, MA.

Astin, H. S., \& Cress, C. M. (2002). Women faculty transforming research universitics. In L. S. Hornig (Ed.), Equal rites, unequal outcomes: Women in American research universities (pp. 53-88). New York, NY: Kluwer. 
Atkins, S. S., Brinko, K. T., Butts, J. A., Claxton, C. S., \& Hubbard, G. T. (2001). Faculty quality of life. In D. Lieberman \& C. Wehlburg (Eds.), To improve the academy: Vol. 19. Resources for faculty, instructional, and organizational development (pp. 323-345). Bolton, MA: Anker.

Atkins, S. S., \& Hageseth, J. A. (1991). The academic chairperson: Leading faculty is like herding cats. Journal of Staff. Program, and Organizational Development, $(1)$, 29-35.

Austin, A. E. (2002). Preparing the next generation of faculty: Graduate school as socialization to the academic career. Journal of Higher Education, 73(1), 94-122.

Austin, A. E., Brocato, J. J., \& Rohrer, J. D. (1997). Institutional missions, multiple faculty roles: Implications for faculty development. In D. Dezure \& M. Kaplan (Eds.), To improve the academy: Vol. 16. Resources for faculty, instructional, and organizational development (pp. 3-20). Stillwater, OK: New Forums Press.

Aycock, A. (2003). Serendipity and SoTL: An ethnographic narrative. In C. Schroeder \& A. Ciccone (Eds.), Learning more about learning (pp. 26-37). Milwaukee, WI: University of Wisconsin-Milwaukee, Center for Instructional and Professional Development.

Baker, G. A., III. (Ed.). (1994). A handbook on the community college in America: Its history mission, and management. Westport, CT: Greenwood Press.

Balch, P. (1999). Part-time faculty are here to stay. Planning for Higher Education, $2 \pi 3), 32-40$.

Baldwin, R. G. (1990, March/April). Faculty vitality beyond the research university: Extending a contextual concept. Journal of Higher Education, 6I(2), 160-180.

Baldwin, R. G. (1998). Academic civility begins in the classroom. Essays on Teaching Excellence, 9. Retrieved May 9, 2004, from htrp://www.unm.edu/-castl/ Castl_Docs/Packet9/Academic\%20Civility\%20Begins\%20in\%20the\%20Class room.heml

Banachowski, G. (1996). Perspectives and perceptions: The use of part-time faculty in community colleges. Community College Review, 24(2), 49-62.

Banta, T. W., \& Associates. (1993). Making a difference: Outcomes of a decade of assessment in higher education. San Francisco, CA: Jossey-Bass.

Banta, T. W., Lund, J. P., Black, K. E., \& Oblander, F. W. (1996). Assessment in practice: Putsing principles to work on college campuses. San Francisco, CA: Jossey-Bass.

Barr, R. B., \& Tagg, J. (1995). From teaching to learning: A new paradigm for undergraduate education. Change, 28(2), 42-47.

Bartlett, T. (2002, March 22). The unkindest cut. Chronicle of Higher Education, p. A10. 
Bass, R. (1999, February). The scholarship of teaching: What's the problem? Inventio: Creative thinking about learning and teaching, I(1). Retrieved April 29, 2004, from http://www.doit.gmu.edu/Archives/feb98/randybass.hem

Baumgartner, L. M. (2001). An update on transformational learning. In S. B. Merriam (Ed.), New directions for adult and continuing education: No. 89. The new update on adult learning theory (pp. 15-24). San Francisco, CA: Jossey-Bass.

Bensimon, E. M., \& Neumann, A. (1993). Redesigning collegiate leadership: Teams and teamwork in higher education. Baltimore, MD: Johns Hopkins University Press.

Bensimon, E. M., Ward, K., \& Sanders, K. (2000). The department chair's role in developing new faculty into teachers and scholars. Bolton, MA: Anker.

Berquist, W. H., Greenberg, E. M., \& Klaum, G. A. (1993). In our fifties: Voices of men and women reinventing their lives. San Francisco, CA: Jossey-Bass.

Bergquist, W. H., \& Phillips, S. R. (1975). Components of an effective faculty development program. Journal of Higher Education, 4Q(2), 177-211.

Bers, T. H., Davis, D., \& Taylor, B. (2000). The use of syllabi in assessments: Unobtrusive indicators and tools for faculty development. Assessment Update, 12, 4-7.

Bevan, J. (1985). Who has the role of building incentives? In R. G. Baldwin (Ed.), New directions for higher education: No. 51. Incentives for faculty vitality (pp. 45-58). San Francisco, CA: Jossey-Bass.

Bishop. C. (1997). The community's college: A history of Johnson County Community College, 1969-1999. Pittsburg, KS: Pittcraft Printing.

Bogdan, R. C., \& Biklen, S. K. (1992). Qualitative research for education: An introduction to theory and methods. Needham Heights, MA: Allyn and Bacon.

Bogen, G. (1978). Performance and vitality as a function of student-faculty fit. In W. C. Kirschling (Ed.), New directions for institutional research, No. 20. Evaluating faculty performance and vitality (pp. 51-67). San Francisco, CA: Jossey-Bass.

Boice, R. (1992). The new faculty member. San Francisco, CA: Jossey-Bass.

Boice, R. (1993). Primal origins and later correctives for midcareer disillusionment. In M. J. Finkelstein \& M. W. LaCelle-Peterson (Eds.), New directions for teaching and learning: No. 55. Developing senior faculty as teachers (pp. 33-41). San Francisco, CA: Jossey-Bass.

Bonwell, C. C., \& Eison, J. A. (1991). Active learning: Creating excitement in the classroom (ASHE-ERIC Higher Education Report No. 1). Washington, DC: George Washington University, Graduate School of Education and Human Services. 
Bothell, T. W., \& Henderson, T. (2004). Evaluating the return on investment of faculty development. In C. M. Wehlburg \& S. Chadwick-Blossey (Eds.), To improve the academy: Vol. 22. Resources for faculty, instructional, and organizational development (pp. 52-70). Bolton, MA: Anker.

Bowden, J. (1989). Curriculum development for conceptual change learning: A phenomenographic pedagogy. Paper presented at the sixth annual (international) Conference of the Hong Kong Educational Research Association, Hong Kong.

Boyd, R. D. (1989). Facilitating personal transformation in small groups, Part I. Small Group Behavior, 20(4), 459-474.

Boyd, R. D. (1991). Personal transformation in small groups: A Jungian perspective. London, England: Routledge.

Boyer, E. L. (1989). The condition of the professoriate: Attitudes and trends, 1989. Princeton, NJ: Carnegie Foundation for the Advancement of Teaching.

Bradley, A. (1999, January 11). Zeroing in on teachers: Quality Counts '99 [Special issue]. Education Week, 18(17), 46-47, 49-52.

Branch, V. (1995). Teaching is "job number one": New faculty at a comprehensive university. Journal of Staff. Program, and Organizational Development, 12(4), 209-218.

Branzburg, J., \& Kennedy, K. (2001, September). Online professional development. Technology and Learning, 22(2), 18-27.

Braskamp, L. A., \& Ory, J. C. (1994). Assessing faculty work: Enhancing individual and institutional performance. San Francisco, CA: Jossey-Bass.

Breneman, D. W. (2002, July 14). For colleges, this is not just another recession. Chronicle of Higher Education, p. B7.

Brewster, D. (2000). The use of part-time faculty in the community college. Inquiry, $5(1), 66-76$.

Bringle, R., \& Hatcher, J. (1999). Reflection in service learning: Making meaning of experience. Educational Horizons, 774), 179-185.

Brinko, K. T. (1993). The pracrice of giving feedback to improving teaching: What is effective? Journal of Higher Education, 64, 575-593.

Brown, M. C. (2000). Involvement with students: How much can 1 give? In M. Garcia (Ed.), Succeeding in an academic career: A guide for faculty of color (pp. 71-88). Westport, CT: Greenwood Press. 
Buchanan, E. (2002). Examining and promoting student learning through a hybrid course environment. In C. Schroeder \& A. Ciccone (Eds.), Models in our midst (pp. 9-19). Milwaukee, WI: University of Wisconsin-Milwaukee, Center for Instructional and Professional Development.

Burnstad, H. M. (1994). Management of human resources in the community college. In G. A. Baker, III (Ed.), A handbook on the community college in America: Its history, mission, and management (pp. 386-395). Westport, CT: Greenwood Press.

Campus Compact. (2000). Introduction to service-learning toolkit: Readings and resources for faculty. Providence, RI: Author.

Carnegie Commission on Higher Education. (1994). The open-door colleges: Policies for community colleges. New York, NY: McGraw-Hill.

Carnevale, A. P., Gainer, L. J., \& Meltzer, A. S. (1990). Workplace basics: The essential skills employers want. San Francisco, CA: Jossey-Bass.

Carter, D. J., \& Ottinger, C. A. (1992). Community college faculty: A profile. Washington, DC: American Council on Education, Division of Policy Analysis and Research.

Carusetra, E. (2001). Evaluating teaching through teaching awards. In C. Knapper \& P. Cranton (Eds.), New directions in teaching and learning: No. 88. Fresh approaches to the evaluation of teaching (pp. 31-40). San Francisco, CA: Jossey-Bass.

Centra, J. A. (1976). Faculty development practices in US colleges and universities. Princeton, NJ: Educational Testing Service.

Centra, J. A. (1985). Maintaining faculty vitality through faculty development. In S. M. Clark \& D. R. Lewis (Eds.), Faculty vitality and institutional productivity: Critical perspectives for higher education. New York, NY: Teachers College Press.

Centra, J. A. (1993). Reflective faculty evaluation: Enhancing teaching and determining faculty effectiveness. San Francisco, CA: Jossey-Bass.

Cerbin, W. (1996). Inventing a new genre: The course portfolio at the University of Wisconsin-La Crosse. In P. Hutchings (Ed.), Making teaching community property: A menu for peer collaboration and peer review (pp. 52-56). Washington, DC: American Association for Higher Education.

Chaffec, E. E. (1997). Listening to the people you serve. In B. L. Cambridge (Ed.), Assessing impact: Evidence and action (pp. 41-50). Washington, DC: American Association for Higher Education.

Chambers, J. (1998). Teaching and learning centers in US higher education: Current and projected roles and services. Unpublished report, Florida Community College, Jacksonville, FL. 
Chang, R. Y., \& Morgan, M. W. (2000). Performance scorecards: Measuring the right things in the real world. San Francisco, CA: Jossey-Bass.

Chapman, J., \& Morley, R. (1999). Collegiate service-learning: Motives underlying volunteerism and satisfaction with volunteer service. Journal of Prevention and Intervention in the Community, 18(1/2), 19-33.

Cherwitz, R. A., \& Sullivan, C. A. (2002, November/December). Intellectual entrepreneurship: A vision for graduate education. Change, 34(6), 23-27.

Chism, N. V. N. (1998). Evaluating TA programs. In M. Marincovich, J. Prostko, \& F. Stout (Eds.), The professional development of graduate teaching assistants (pp. 249-262). Bolton, MA: Anker.

Chism, N. V. N. (1999). Peer review of teaching: A sourcebook. Bolton, MA: Anker.

Chism, N. V. N. (2003, March 14). Summary of responses on user records. Message posted to POD electronic mailing list, archived at http://listserv.nd.edu/cgibin/wa?A2=ind0303\&L=pod $\& \mathrm{O}=\mathrm{A} \& \mathrm{P}=7509$

Chism, N. V. N. (2004). Characteristics of effective teaching in higher education: Between definitional despair and certainty. Manuscript submitted for publication.

Chism, N. V. N., \& Szabo, B. (1997). How faculty development programs evaluate their services. Journal of Staff, Program, and Organizational Development, 15(2), $55-62$.

Chism, N. V. N., \& Szabo, B. (1997). Teaching awards: The problem of assessing` their impact. In D. DeZure \& M. Kaplan (Eds.), To improve the academy: Vol. I6. Resources for faculy, instructional, and organizational development (pp. 181-200). Stillwater, OK: New Forums Press.

Chitouras, J. (1993. Spring). Esoteric sound and color. Gnosis, 27, 36-40.

Civian, J. T., Arnold, G., Gamson, Z. F., Kanter, S., \& London, H. B. (1996). Implementing change. In J. G. Gaff, J. L. Ratcliff, \& Associates (Eds.), Handbook of the undergraduate curriculum: $A$ comprehensive guide to purposes, structures, practices, and change (pp. 647-660). San Francisco, CA: Jossey-Bass.

Clark, B. (1985). The academic life. Princeton, NJ: Princeton University Press.

Clark, S., \& Corcoran, M. (1985). Individual and organizational contributions to faculty vitality: An institutional case study. In S. M. Clark \& D. R. Lewis (Eds.), Faculty vitality and inssitutional productivity: Critical perspectives for higher education (pp. 112-138). New York, NY: Teachers College Press.

Coffman, S. J. (2002). Ten strategies for getting students to take responsibility for their learning. College Teaching, 51, 2-4. 
Cohen, A. M., \& Brawer, F. B. (1987). The collegiate function of community colleges: Fostering higher learning through curriculum and student transfer. San Francisco, CA: Jossey-Bass.

Cohen, A. M., \& Brawer, F. B. (1996). The American community college. San Francisco, CA: Jossey-Bass.

Cohen, P. A., \& Herr, G. (1982). Using an interactive feedback procedure to improve college teaching. Teaching of Psychology, 9, 138-140.

Colby, A., Ehrlich, T., Beaumont, E., \& Stephens, J. (2003). Educating citizens: Preparing America's undergraduates for lives of moral and civic responsibility. San Francisco, CA: Jossey-Bass.

Committee on Science, Engineering, and Public Policy. (1995). Reshaping the graduate education of scientists and engineers. Washington, DC: National Academy Press.

Cooper, D. (1998). Reading, writing, and reflection. In R. A. Rhoads \& J. Howard (Eds.), Academic service learning: A pedagogy of action and reflection (pp. 47-56). San Francisco, CA: JosseyBass.

Cox, M. D. (2001). Faculty learning communities: Change agents for transforming institutions into learning organizations. In D. Lieberman \& C. Wehlburg (Eds.), To improve the academy: Vol. 19. Resources for faculty instructional, and organizational development (pp. 69-93). Bolton, MA: Anker.

Cranton, P. (1992). Working with adult learner. Toronto, Ontario: Wall \& Emerson.

Cranton, P. (1994, November/December). Self-directed and transformative instructional development. Journal of Higher Education, 65(6), 726-744.

Cranton, P. (1996). Professional development as transformative learning: New perspectives for teachers of adults. Journal of Higher Education, 65, 726-744.

Cranton, P. (1997). New directions for adule and continuing education: No. 74: Transformative learning in actions: Insights from practice. San Francisco, CA: Jossey-Bass.

Cranton, P. (2002, Spring). Teaching for transformation. In J. M. Ross-Gordon (Ed.), New directions for adult and continuing education: No. 93. Contemporary viewpoints on teaching adults effectively (pp. 63-71). San Francisco, CA: Jossey-Bass.

Crawley, A. (1995). Faculty development programs at research universities: Implications for senior faculty renewa!. In E. Neal \& L. Richlin (Eds.), To improve the academy: Vol. 14. Resources for faculty, instructional, and onganizational development (pp. 65-90). Stillwater, OK: New Forums Press. 
Creamer, E. G. (1998). Assessing faculty publication productivity: Issues of equity (ASHE-ERIC Higher Education Report, 26[2]). Washington, DC: George Washington University, Graduate School of Education and Human Development.

Cross, K. P. (1993, February/March). Involving faculty in TQU. AACC Journal, $15-20$.

Cross, K. P., \& Steadman, M. H. (1996). Classroom research: Implementing the scholarship of teaching. San Francisco, CA: Jossey Bass.

Cuban, L. (1999). How scholars trumped teachers: Change without reform in university curriculum, teaching, and research, 1890-1990. New York, NY: Teachers College Press.

Daley, B. (2002). Facilitating adult learning in higher education. In C. Schroeder \& A. Ciccone (Eds.), Models in our midst (pp. 21-31). Milwaukee, WI: University of Wisconsin-Milwaukee, Center for Instructional and Professional Development.

Darwin, T. J. (2000). Professional development as intellectual opportunity. Paper presented at the National Communication Association Conference, Seattle, WA. Retrieved November 5, 2003, from https://webspace.utexas.edu/cherwirz/www/ie/td.html

Deci, E., Kasser, T., \& Ryan, R. (1997). Self-determined teaching: Opportunities and obstacles. In J. Bess (Ed.), Teaching well and liking it: Motivating faculty to teach effectively (pp. 57-71). Baltimore, MD: Johns Hopkins Universiry Press.

Deegan, W. (1985). Renewing the American community college: Priorities and strategies for effective leadership. San Francisco, CA: Jossey-Bass.

DeZure, D. (Ed.). (2000). Learning from change: Landmarks in teaching and learning in higher education from Change magazine 1969-1999. Sterling, VA: Stylus.

Diamond, R. M. (2002). Faculty, instructional, and organizational development: Options and choices. In K. H. Gillespie, L. R. Hilsen, \& E. C. Wadsworth (Eds.), $A$ guide to faculty development: Practical advice, examples, and resources (pp 2-8). Bolton, MA: Anker.

Dieker, L. (2002). Inquiry into video streaming. In C. Schroeder \& A. Ciccone (Eds.), Models in our midst (pp. 35-39). Milwaukee, WI: University of Wisconsin-Milwaukee, Center for Instructional and Professional Development.

Diener, T. (1986). Growth of an American invention: A documentary history of the junior and community college movement. Westport, CT: Greenwood Press.

Dirkx. J. M. (1998). Transformative learning theory in the practice of adult education: An overview. PAACE Journal of Lifelong Learning, 7, 1-14. 
Doherty, A., Riordan, T., Roth, J. (Eds.). (2002). Student learning: A central focus for institutions of higher education. Milwaukee, WI: Alverno College Institute.

Driscoll, A., Holland, B., Gelmon, S., \& Kerrigan, S. (1996). An assessment model for service-learning: Comprehensive case studies of impact on faculty, students, community, and institution. Michigan Joumal of Community Service Leaming, 3, 66-71.

Dunlap, M. (1998). Methods of supporting students' critical reflection in courses incorporating service-learning. Teaching of Psychology, 25(3), 208-210.

Eaton, J. S. (1994). Strengthening collegiate education in community colleges. San Francisco, CA: Jossey-Bass.

Ebben, J., \& Maher, T. (1979, May). Capturing institutional vitality. Paper presented at the annual forum of the Association for Institutional Research, San Diego, CA.

Eble, K. E., \& McKeachie, W. J. (1985). Improving undergraduate education through faculty development. San Francisco, CA: Jossey-Bass.

Elbow, P. (1981). Writing with power. New York, NY: Oxford University Press.

Elbow, P. (1986). Embracing contraries: Explorations in teaching and learning. New York, NY: Oxford University Press.

Eliot, T. S. (1964). Selected essays. New York, NY: Harcourt, Brace, \& World.

Ellner, C. L., \& Barnes, C. P. (Eds.). (1983). Studies of college teaching: Experimental results, theoretical interpretations, and new perspectives. Lexington, MA: D.C. Heath.

Epper, R., \& Bates, A. (2001). Teaching faculty how to use technology: Best practices from leading institutions. Phoenix, AZ: Oryx Press/American Council on Education.

Erickson, G. (1986). A survey of faculty development practices. In M. Svinicki, J. Kurfiss, \& J. Stone (Eds.), To improve the academy: Vol. 5. Resources for student, faculty, and institutional development (pp. 182-196). Stillwater, OK: New Forums Press.

Erickson, G. R., \& Erickson, B. L. (1979). Improving college teaching: An evaluation of a teaching consultation procedure. Journal of Higher Education, 50, 670-683.

Erickson, J., \& O'Conner, S. (2000). Service-learning: Does it promore or reduce prejudice? In C. O'Grady (Ed.), Integrating service learning and multicultural education in colleges and universities (pp. 59-70). Mahwah, NJ: Lawrence Erlbaum. 
Ewell, P. (2002). Perpetual movement: Assessment after twenty years. Paper presented at the American Association for Higher Education Assessment Conference, Boston, MA. Retrieved May 6, 2004, from http://www.aahe.org/assessment/2002/ PlenariesForFrames.htm

Eyler, J., \& Giles, D. (1999). Where's the learning in service-learning? San Francisco, CA: Jossey-Bass.

Fassel, D. (1990). Working ourselves to death: And the rewards of recovery. New York, NY: HarperCollins.

Felder, R. M., \& Brent, R. (1996). Navigating the bumpy road to student-centered instruction. College Teaching. 44, 43-47. Retrieved December 3, 2003, from http://www.ncsu.edu/felder-public/Papers/Resist.html

Ferren, A. S., \& McCafferty, J. K. (1992). Reforming college mathematics. College teaching, $40(3), 87-90$.

Fields, R. (1962). The community college movement. New York, NY: McGraw-Hill.

Fife, J. (1991). Foreword. In W. Toombs \& W. Tierney, Meeting the mandate: Renewing the college and departmental curriculum (p. xiii). Washington, DC: George Washington University, School of Education and Human Development.

Fink, D. L. (2003). Creating significant learning experiences: An integrated approach to designing college courses. San Francisco, CA: Jossey-Bass.

Finkelstein, M. J., \& LaCelle-Peterson, M. W. (1992). New and junior faculty: A review of the literature. In M. D. Sorcinelli \& A. E. Austin (Eds.), Developing new and junior faculty (pp. 5-14). San Francisco, CA: Jossey-Bass.

Finkelstein, M. J., Seal, R. K., \& Schuster, J. H. (1998). The new academic generation: A profession in transformation. Baltimore, MD: Johns Hopkins University Press.

Flannery, D., \& Ward, K. (1999). Service learning: A vehicle for developing cultural comperence in health education. American Journal of Health Behavior, 23(5), 323-331.

Foster, S. (2000). Teaching partners program: Analysis of furst interviews. Unpublished report.

Foster, W. (1989). Toward a critical practice of leadership. In J. Smyth (Ed.), Critical perspectives on educational leadership (pp. 39-63). London, England: Falmer Press.

Francis, J. B. (1976). An evaluation of programs to recognize and reward teaching excellence. Buffalo, NY: State University of New York at Buffalo, Department of Higher Education. (ERIC Document Reproduction Service No. ED156723) 
Fuerst, P. A. (1984). University student understanding of evolutionary biology's place in the creation/evolution controversy. Ohio Journal of Science, 84(5), 218-228.

Fulton, R. D. (2000, May). The plight of part-timers in higher education. Change, $32(3), 38-42$.

Furco, A. (1996). Service-learning: A balanced approach to experiential education. Expanding boundaries: Serving and learning. Washington, DC: Corporation for National Service.

Gaff, J. G. (1975). Toward faculty renewal: Advances in faculty, instructional, and organization development. San Francisco, CA: Jossey-Bass.

Gaff, J. G. (2002, November/December). Preparing future faculty and doctoral education. Change, 34(6), 63-66.

Gappa, J. M. (1984). Part-time faculty: Higher education at a crossroads (ASHE-ERIC Higher Education Research Report No. 3). Washington, DC: Association for the Study of Higher Educarion.

Gappa, J. M., \& Leslie, D. W. (1993). The invisible faculty: Improving the status of part-timers in higher education. San Francisco, CA: Jossey-Bass.

Gappa, J. M., \& Leslie, D. W. (1997). Two faculties or one? The conundrum of parttimers in a bifurcated workforce (Inquiry No. 6). Washington, DC: American Association for Higher Education.

Garcia, M. (2000). Succeeding in an academic career: A guide for faculty of color. Westport, CT: Greenwood Press.

Gardiner, L. F. (1996). Redesigning higher education: Producing dramatic gains in student learning (ASHE-ERIC Higher Education Report, 23[7]). San Francisco, CA: Jossey-Bass.

Geisel, T. (1990). Oh, the places you'll go! New York, NY: Random House.

Gelmon, S., Holland, B., Driscoll, A., Spring, A., \& Kerrigan, S. (2001). Assessing service-learning and civic engagement: Principles and sechniques. Providence, $\mathrm{R}$ : Campus Compact.

Gibbs, G. (1999). Improving teaching, learning, and assessment. Journal of Geography in Higher Education, 23, 147-155.

Giddens, A. (1984). The constitution of society. Los Angeles, CA: University of California Press.

Gillespic, K. H. (Ed.). (1998). New directions for teaching and learning: No. 76. The impact of technology on faculty development, life, and work. San Francisco, CA: Jossey-Bass. 
Gillespie, K. H., Hilsen, L. R., \& Wadsworth, E.C. (Eds.). (2002). A guide to faculty development: Practical advice, examples, and resources. Bolton, MA: Anker.

Gleazer, E. (1967). Preparation of junior college teachers. Educational Record, 48(2), $147-152$.

Golde, C. M., \& Dore, T. M. (2001). At cross purposes: What the experiences of today's graduate students reveal about doctoral education. Philadelphia, PA: Pew Charitable Trusts. Retrieved April 19, 2002 from http://www.phd-survey.org

Golin, S. (1990). Peer collaboration and student interviewing: The master faculty program. AAHE Bulletin, 43(4), 9-10.

Gordon, V. N., Habley, W. R., \& Associates. (2000). Academic advising: A comprehensive handbook. San Francisco, CA: Jossey-Bass.

Grabove, V. (1997, Summer). The many facets of transformative learning theory and practice. In P. Cranton (Ed.), New directions for adult and continuing education: No. 74. Transformative learning in action: Insights from practice (pp. 89-95). San Francisco, CA: Jossey-Bass.

Graesser, A. C., Person, N. K., Hu, X. (2002). Improving comprehension through discourse processing. In D. F. Halpern \& M. D. Hakel (Eds.), New directions for teaching and learning: No. 89. Applying the science of learning to university teaching and beyond (pp. 33-44). San Francisco, CA: Jossey-Bass.

Graf, D., \& Wheeler, D. (1996). Defining the membership: The POD membership survey. Ames, IA: Professional and Organizational Development Network in Higher Education.

Gravett, S. (1996). Conceptual change regarding instruction: The professional enhancement of faculty. Journal of Staff. Program, and Organizational Development, 13(3), 207-214.

Grubb, W. N., \& Associates. (1999). Honored but invisible: An inside look at teaching in community colleges. New York, NY: Routledge.

Gugerty, C., \& Swezey, E. (1996). Developing campus-community relationships. In B. Jacoby \& Associates (Eds.), Service-learning in bigher education: Concepts and practices (pp. 92-108). San Francisco, CA: Jossey-Bass.

Gullatt, D., \& Weaver, S. (1997, October). Use of faculty development activities to improve the effectiveness of U.S. institutions of higher education. Paper presented at the meeting of the Professional and Organizational Development Network in Higher Education, Nines Ciry, FL. 
Habley, W. R., \& Crockett, D. S. (1988). The third ACT national survey of academic advising. In W. H. Habley (Ed.), The status and future of academic advising: Problems and promise (pp. 11-76). Iowa City, IA: ACT National Center for the Advancement of Educational Priorities.

Haeger, J. D. (1998). Part-time faculty, quality programs, and economic realities. In D. W. Leslie (Ed.), New directions for higher education: No. 104. The growing use of part-time faculty: Understanding causes and effects (pp. 81-88). San Francisco, CA: Jossey-Bass.

Hageseth, J. A., \& Atkins, S. S. (1988). Assessing faculty quality of life. In J. G. Kurfiss (Ed.), To improve the academy: Vol. 7. Resources for ssudent, faculty, and institutional development (pp. 109-120). Stillwater, OK: New Forums Press.

Hageseth, J. A., \& Atkins, S. S. (1989). Building university community: Where's the staff? Journal of Staff, Program, and Organizational Development, $\pi 4), 173-180$.

Hake, R. R. (1998). Interactive-engagement versus traditional methods: A six-thousand-student survey of mechanics test data for introductory physics courses. American Journal of Physics, 6Q(1), 64-74.

Hammons, J. (1983). Faculty development: A necessary corollary to faculty evaluation. In A. M. Cohen \& F. B. Brawer (Eds.), New directions for community colleges: No. 41. Evaluating faculty and staff (pp. 75-82). San Francisco, CA: JosseyBass.

Harris, M. (1987). Teaching and religious imagination: An essay in the theology of teaching. New York, NY: HarperCollins.

Hart, R. P., \& Burks, D. M. (1972). Rhetorical sensitivity and social interaction. Speech Monographs, 39, 75-91.

Heffernan, K. (2001). Fundamentals of service-learning course construction. Providence, $\mathrm{RI}$ : Campus Compact.

Heifetz, R. A. (1994). Leadership without easy answers. Cambridge, MA: Harvard University Press.

Hessmiller, J., \& Brown, K. (1995). Learning to act: Service-learning integrates theory and practice. In J. Eby (Ed.), Service-learning: Linking academics and the community (pp. 213-220). Grantham, PA: Pennsylvania Campus Compact.

Higher Education Research Institute. (1999). The American college teacher: National norms for 1998-99 HERI faculty survex. Los Angeles, CA: University of California. 
Ho, A. S. P. (1998). A conceptual change staff development programme: Effects as perceived by the participants. International Journal for Academic Development, $3(1), 25-38$.

Hoerner, J., Clowes, D., \& Impara, J. (1991). Professional development programs in community and technical colleges: Are occupational-rechnical faculty needs well served? Journal of Studies in Technical Careers, 13(4), 351-360.

Hord, S. M., Rutherford, W. L., Huling-Austin, L., \& Hall, G. E. (1987). Taking charge of change. Alexandria, VA: Association for Supervision and Curriculum Development.

Howard, J. (1998). Academic service learning: A counternormative pedagogy. In R. A. Rhoads \& J. Howard (Eds.), Academic service learning: $A$ pedagogy of action and reflection (pp. 21-29). San Francisco, CA: Jossey-Bass.

Howard, J. (Ed.). (1993). Praxis I: A faculty casebook on community service learning. Ann Arbor, MI: OCSL Press.

Huba, M. E., \& Freed, J. E. (2000). Learner-centered assessment on college campuses: Shifing the focus from teaching to learning. Needham Heights, MA: Allyn and Bacon.

Hubbard, G. T., \& Atkins, S. S. (1995). The professor as a person: The role of faculty well-being in faculty development. Innovative Higher Education, 20, 117-128.

Hubbard, G. T., Atkins, S. S., \& Brinko, K. T. (1998). Holistic faculty development: Supporting personal, professional, and organizational well-being. In M. Kaplan (Ed.), To improve the academy: Vol. 17. Resources for faculty, instructional, and organizational development (pp. 35-49). Stillwater, OK: New Forums Press.

Huber, M. T., \& Morreale, S. P. (Eds.). (2002). Disciplinary styles in the scholarship of teaching and learning: Exploring common ground. Washington DC: American Association for Higher Education and the Carnegie Foundation for the Advancement of Teaching.

Hurtado, S., Milem, J. F., Clayton-Pedersen, A. R., \& Allen, W. R. (1998). Enhancing campus climates for racial/ethnic diversity: Educational policy and practice. Review of Higher Education, 21(3), 279-302.

Hutchings, P. (1996). The peer review of teaching: Progress, issues, and prospects. Innovative Higher Education, 20(4), 221-234.

Hutchings, P. (2000). Opening lines: Approaches to the scholarship of teaching and learning. Menlo Park, CA: The Carnegic Foundation for the Advancement of Teaching. 
Hutchings, P., \& Marchese, T. (1990, September/October). Watching assessment questions, stories, prospects. Change, 22(5), 12-38.

Imel, S. (1998). Transformative learning in adulthood. Washington, DC: Office of Educational Research and Improvement. (ERIC Document Reproduction Service No. ED42326). Retrieved April 29, 2004, from http://www.cete.org/acve/ docgen.asp?tbl=digests\&ID $=53$

Impara, J., Hoerner, J., Clowes, D., \& Allkins, M. (1991). Professional development programs: A comparison of full-time and part-time occupational faculty. Community Services Catalyst, 21(2), 8-12.

Jacobs, F. (1998). Using part-time faculty more effectively. In D. W. Leslie (Ed.), New directions for higher education: No. 104. The growing use of part-time faculty: Understanding causes and effects (pp. 9-17). San Francisco, CA: Jossey-Bass.

Jacoby, B. (1996). Service-learning in today's higher education. In B. Jacoby \& Associates (Eds.), Service-learning in higher education: Concepts and practices (pp. 3-25). San Francisco, CA: Jossey-Bass.

Jacoby, B., \& Associates. (Eds.). (1996). Service-learning in higher education: Concepts and practices. San Francisco, CA: Jossey-Bass.

Johnson County Community College. (2001). Fact sheet. Overland Park, KS: Author.

Johnson Counry Communiry College. (2001-2002). College catalog. Overland Park, KS: Author.

Johnson County Community College \& The League for Innovation in the Community College. (2000). Internal document. Overland Park, KS: Author.

Jones, E. A., \& Ratcliff, J. R. (1990, April). Is a core curriculum best for everybody? The effect of different patterns of coursework on the general education of high-and lowability students. Paper presented at the annual meeting of the American Educational Research Association, Boston, MA.

Kalivoda, P., Broder, J., \& Jackson, W. K. (2003). Establishing a teaching academy: Cultivation of teaching at a research university campus. In C. M. Wehlburg \& $S$. Chadwick-Blossey (Eds.), To improve the academy: Vol. 21. Resources for faculty, instructional, and organizational development (pp. 79-92). Bolton, MA: Anker.

Karasik, R. (in press). Breaking the time barrier: Helping students "find the time" to do intergenerational service-learning. Gerontology o Geriatrics Education.

Karasik, R., \& Berke, D. (2001). Classroom and community: Experiential education in family studies and gerontology. Joumal of Teaching in Marriage and Family: Innovations in Family Science Education. 1(4), 13-38. 
Karasik, R., Maddox, M., \& Wallingford, M. (in press). Intergenerational servicelearning across levels and disciplines: "One size (does not) fit all." Gerontology o Geriatrics Education.

Karpiak, 1. (2000). The "second call": Faculty renewal and recommitment at midlife. Quality in Higher Education, Q(2), 125-134.

Keim, M. C., \& Biletzky, P. (1999, December). Teaching methods used by part-time community college faculty. Community College Journal of Research \& Practice, 23, 727-737.

Kekale, J. (1999). "Preferred" patterns of academic leadership in different disciplinary (sub)culcures. Higher Education, 37, 217-238.

Keller, P. (1982). Getting at the core: Curricular reform at Harvard. Cambridge, MA: Harvard University Press.

Kelley, W., \& Wilhun, L. (1970). Teaching in the community junior college. New York, NY: Appleton-Century-Crofts.

Killion, J. P. (2000, Summer). Log on to learn. Journal of Staff Development, 21(3), 48-53.

Kotter, J. P. (1996). Leading change. Boston, MA: Harvard Business School Press.

Kottkamp, R. (1990). Means for facilitating reflection. Education and Urban Society, 22, 182-203.

Kozma, R. (1985, May/June). A grounded theory of instructional innovation in higher education. Journal of Higher Education, 56(3), 300-319.

Laden, B. V., \& Hagedorn, L. S. (2000). Job satisfaction among faculty of color in academe: Individual survivors or institutional transformers? In L. S. Hagedorn (Ed.), New directions for institutional research: No. 105. What contributes to job satisfaction among faculty and staff (pp. 57-66). San Francisco, CA: Jossey-Bass.

Langley, D. J., O'Connor, T. W., \& Welkener, M. M. (2004). A transformative model for designing professional development activities. In C. M. Wehlburg \& S. Chadwick-Blossey (Eds.), To improve the academy: Vol. 22. Resources for faculty, instructional, and organizational development (pp. 145-155). Bolton, MA: Anker.

Lankard, B. A. (1993). Part-time instructors in adult and vocational education. Columbus, $\mathrm{OH}$ : ERIC Clearinghouse on Adult, Career, and Vocational Education. (ERIC Reproduction Service No ED363797)

LaPidus, J. B. (1997). Doctoral education: Preparing for the future. Washington, DC: Council of Graduate Schools. Retrieved September 10, 2002, from http://www.cgsnet.org/pdf/doctoraledpreparing.pdf 
Lazerson, M., Wagener, U., \& Shumanis, N. (2000, May/June). Teaching and learning in higher education, 1980-2000. Change, 32(3), 13-19.

Leslie, D. W. (1998). New directions for research, policy development, and practice. In D. W. Leslie (Ed.), New directions for bigher education: No. 104. The growing use of part-time faculty: Understanding causes and effects (pp. 95-100). San Francisco, CA: Jossey-Bass.

Levine, A. (1978). Handbook on undergraduate curriculum: $A$ report for the Carnegie Council on Policy Studies in Higher Education. San Francisco, CA: Jossey-Bass.

Levinson-Rose, J., \& Menges, R. (1981). Improving college teaching: A critical review of research. Review of Educational Research, 51, 403-434.

Leviton, R. (1994, January/February). Healing vibrations. Yoga Journah, 1, 59-64, 81-83.

Lewis, K. G. (1996). Faculty development in the US: A brief history. International Journal of Academic Development, 1(2), 26-33.

Lick, D. W. (2002). Leadership and change. In R. M. Diamond (Ed.), Field guide to academic leadership (pp. 27-47). San Francisco, CA: Jossey-Bass.

Lieberman, D. A., \& Guskin, A. E. (2003). The essential role of faculty development in new higher education models. In C. M. Wehlburg \& S. Chadwick-Blossey (Eds.), To improve the academy: Vol. 21. Resources for faculy, instructional, and organizational development (pp. 257-272). Bolton, MA: Anker.

Lindquist, J. (1996). Strategies for change. In J. G. Gaff, J. L. Ratcliff, \& Associates (Eds.), Handbook of the undergraduate curriculum: A comprehensive guide to purposes, structures, practices, and change (pp. 633-660). San Francisco, CA: JosseyBass.

Loacker, G., \& Mentkowski, M. (1993). Creating a culture where assessment improves learning. In T. W. Banta (Ed.), Making a difference: Outcomes of a decade of assessment in higher education (pp. 5-24). San Francisco, CA: Jossey-Bass.

Loeb, P. (1994). Generations at the crossroads: Apathy and action on the American campus. New Brunswick, NJ: Rutgers University.

Loeb, P. (1999). Soul of a citizen: Living with conviction in a cynical time. New York, NY: St. Martin's Griffin.

London, H. (1978). The culture of a community college. New York, NY: Praeger.

Lopez, C. L. (1999). A decade of assessing student learning: What have we learned; what's next? Chicago, IL: North Ceneral Association of Colleges and Schools Commission on Institutions of Higher Education. 
Lovitts, B. E., \& Nelson, C. (2000, November/December). The hidden crisis in graduate education: Attrition from Ph.D. programs. Academe, 8Q6). Retrieved May 9, 2004, from http://www.aaup.org/publications/Academe/2000/00nd/ND00LOVI.HTM

Lowman, J. (1994). Professors as performers and motivators. College Teaching, 42, 137-141.

Lucas, C. (1994). American higher education: A history. New York, NY: St. Martin's Press.

Lyons, R. E., Kysilka, M. L., \& Pawlas, G. E. (1999). The adjunct professor's guide to success. Boston, MA: Allyn and Bacon.

Maher, T. H. (1982, June). Institutional vitality in higher education (AAHE-ERIC Higher Education Research Currents). (ERIC Document Reproduction Service No. ED216668)

Matlin, M. W. (2002). Cognitive psychology and college-level pedagogy: Two siblings that rarely communicate. In D. F. Halpern \& M. D. Hakel (Eds.), New directions for teaching and learning: No. 89. Applying the science of learning to university teaching and beyond (pp. 87-103). San Francisco, CA: Jossey-Bass.

Maxwell, W. E., \& Kazlauskas, E. J. (1992). Which faculry development methods really work in community colleges? A review of research. Community/Junior College Quarterly, 16, 351-360.

Mazur, E. (1997). Peer instruction: A user's manual Upper Saddle River, NJ: PrenticeHall.

McAlpine, L., \& Harris, R. (2002). Evaluating teaching effectiveness and teaching improvement: $A$ language for institutional policies and academic development practices. International Journal of Academic Development, $7(1), 7-17$.

McCall, G., \& Simmons, J. (1969). Issues in participant observation: $A$ text and reader. Reading, MA: Addison-Wesley.

McEwen, M. (1996). Enhancing student learning and development through servicelearning. In B. Jacoby \& Associates (Eds.), Service-learning in higher education: Concepts and practices (pp. 53-91). San Francisco, CA: Jossey-Bass.

McKeachie, W. J., Lin, Y-G, Daugherty, M., Moffett, M. M., Neigler, C., Nork, J., et al. (1980). Using student ratings and consultation to improve instruction. British Journal of Educational Psychology, 50, 168-174.

McKenna, M., \& Rizzo, E. (1999). Student's perceptions of the "learning" in servicelearning courses. Journal of Prevention of Intervention in the Community, 18(1/2), 111-123. 
Meleish, J. (1968). The lecture method. Cambridge, England: Cambridge Institute of Education.

McNaught, C., \& Anwyl, J. (1993). Awards for teaching at Australian universities (Centre for the Study of Higher Education Research Working Papers No. 93.1). Victoria, Australia: University of Melbourne. (ERIC Document Reproduction Service No. ED368291)

McNeel, S. P. (1994). College teaching and student moral development. In J. R. Rest \& D. Narváez (Eds.), Moral development in the professions: Psychology and applied ethics (pp. 27-49). Mahwah, NJ: Lawrence Erlbaum.

Menges, R. J. (1996). Awards to individuals. In M. D. Svinicki \& R. J. Menges (Eds.), New directions in teaching and learning: No. 65. Honoring exemplary teaching (pp. 3-9). San Francisco, CA: Jossey-Bass.

Menges, R. J. (1996). Experiences of newly hired faculty. In L. Richlin \& D. DeZure (Eds.), To improve the academy: Vol. 15: Resources for faculty instructional, and organizational development (pp. 169-182). Stillwater, OK: New Forums Press.

Merriam, S. B. (1997). Qualitative research and case study applications in education. San Francisco, CA: Jossey-Bass.

Merton, T. (1965). The way of Chuang Tzu. New York, NY: New Directions.

Meyers, R. (2003). An examination of students' use of evidence in group quiz discussions. In C. Schroeder \& A. Ciccone (Eds.), Learning more about learning (pp. 15-23). Milwaukee, WI: University of Wisconsin-Milwaukee, Center for Instructional and Professional Development.

Mezirow, J. (1990). Fostering critical reflection in adulthood: A guide to transformative and emancipatory learning. San Francisco, CA: Jossey-Bass.

Mezirow, J. (1991). Transformative dimensions of adult learning. San Francisco: JosseyBass.

Mezirow, J. (1997, Summer). Transformative learning: Theory to practice. In P. Cranton (Ed.), New directions for aduls and continuing education: No. 74. Transformative learning in action: Insights from practice (pp. 5-12). San Francisco, CA: Jossey-Bass.

Mezirow, J. (2000). Learning to think like an adult: Core concepts of transformation theory. In J. Mezirow \& Associates (Eds.), Learning as transformation: Critical perspectives on a theory in progress (pp. 3-34). San Francisco, CA: Jossey-Bass. 
Middendorf, J. K. (1998). A case study in getting faculty to change. In M. Kaplan \& D. Lieberman (Eds.), To improve the academy: Vol. 17. Resources for faculty, instructionah and organizational development (pp. 203-224). Stillwater: OK: New Forums Press.

Middendorf, J. K. (2000). Finding key faculty to influence change. In M. Kaplan \& D. Lieberman (Eds.), To improve the academy: Vol. 18. Resources for faculty, instructional, and organizational development (pp. 83-93). Bolton, MA: Anker.

Middleton, A. (1987, October). Teaching awards and tokenism. Teaching Professor, $I(8), 3-4$.

Miles, M., \& Fullan, M. (1992, June). Getring reforms right: What works and what doesn't. Phi Delta Kappa, 73(10), 745-752.

Miles, M., \& Huberman, A. (1984). Qualitative data analysis: $A$ sourcebook of new methods. Beverly Hills, CA: Sage.

Miller, D. J., \& Ratcliff, J. L. (1986). Analysis of professional activities of Iowa Community College faculty. Community/Junior College Journal, 10, 317-343.

Miller, R. I., Finley, C., \& Shedd Vancko, C. (2000). Evaluating, improving, and judging faculy performance in two-year colleges. Westport, CT: Bergin \& Garvey.

Milloy, P. M., \& Brooke, C. (2004). Beyond bean counting: Making faculty development needs assessment more meaningful. In C. M. Wehlburg \& $S$. ChadwickBlossey (Eds.). To improve the academy: Vol. 22. Resources for faculty, instructional, and organizational development (pp. 71-92). Bolton, MA: Anker.

Mintz, J. (1999, Spring). Faculty development and teaching: A holistic approach. Liberal Education, 85, 32-37.

Monroe, C. (1972). Profile of the community college: $A$ handbook. San Francisco, CA: Jossey-Bass.

Montell, G. (1999). In on-line survey, graduate students in science rate their doctoral programs. Chronicle of Higher Education, p. Al6.

Morphew, C. C., Twombly, S. B., \& Wolf-Wendel, L. E. (2001). Two urban community colleges and an elite private liberal arts college. Community College Review, 29(3), 1-21.

Morton, K. (1996). Issues related to integrating service-learning into the curriculum. In B. Jacoby \& Associates (Eds.), Service-learning in higher education: Concepts and practices (pp. 276-296). San Francisco, CA: Jossey-Bass. 
Mullinix, B. B., \& Harr, C. (2003). Faculy-centered program development. West Long Branch, NJ: Monmouth University, Faculty Resource Center. Retrieved December 11, 2003, from http://its.monmouth.edu/trainingGues//POD-BIA/Mullinix-Harr \%20BIA-FacCentrDev-HO.doc

Murray, J. P. (1995). Faculty (mis)development in Ohio two-year colleges. Community College Journal of Research and Practice, 19, 549-593.

Murray, J. P. (1999). Faculty development in a national sample of community colleges. Community College Review, 273), 47-64.

Murray, J. P. (2002). Faculty development in SACS-accredited community colleges. Community College Review, 2X4), 50-67.

National Association of Graduate-Professional Students. (2001). The 2000 national doctoral program survey. Washington, DC: Auchor. Retrieved September 10, 2002, from http://survey.nagps.org

National Center for Education Statistics. (2002). A profile of part-time faculty: Fall 1998. Washington, DC: U.S. Department of Education.

National Education Association Higher Education Research Center. (2001). Parttime faculty. Update, 74 ), $1-4$.

National Research Council. (1992). Educating mathematical scientists: Doctoral study and the postdoctoral experience in the United States. Washington, DC: National Academy Press.

National Survey of Student Engagement. (2001). Resules from St. Lawrence University. Bloomington, IN: Indiana University. Retrieved December 1, 2003, from http://www.indiana.edu/-nsse/

Neptune, C. (2001). Opportunities for excellence: Brofessionalism and the two-year college mathematics faculty. Memphis, TN: American Mathematical Association of Two-Year Colleges.

Nerad, M., \& Cerny, J. (1999, Fall). From rumors to facts: Career outcomes of English Ph.D.s. Council of Graduate Schools Communicator, 32(7), 1-11. Retrieved May 9, 2004, from hetp://www.grad.washington.edu/envision/PDF/TenYears Later.pdf

Nerad, M., \& Cerny, J. (2000). Improving doctoral education: Recommendations from the "Ph.D.s 10 years later study." Council of Graduate Schools Communicator, 33(2), 6. Retrieved May 9, 2004, from snet.org/PublicationsPolicyRes/ communicatorpdfs/2000/march2000.pdf

Nyquist, J. D. (2002, November/December). The Ph.D.: A tapestry of change for the 21 st century. Change, 34(G), 12-20. 
Nyquist, J. D., \& Sprague, J. (1998). Thinking developmentally about TAs. In M. Marincovich, J. Prostko, \& F. Stout (Eds.), The professional development of graduate teaching assistants (pp. 61-88). Bolton, MA: Anker.

O'Banion, T. (1994). Teaching and learning: A mandate for the nineties. Community College Journal, 64(4), 21-25.

O'Banion, T. (1994). Teaching and learning in the community college. Washington, DC: Community College Press.

Olguin, E., \& Schmitz, B. (1996). Transforming the curriculum through diversity. In J. G. Gaff, J. L. Ratcliff, \& Associates (Eds.), Handbook of the undergraduate curriculum: A comprehensive guide to purposes, structures, practices, and change (pp. 436-456). San Francisco, CA: Jossey-Bass.

Olson, K. (2003). Using comparative practice to test the veracity of learning theories designed to promote "deep understanding." In C. Schroeder \& A. Ciccone (Eds.), Learning more about learning (pp. 38-49). Milwaukee, WI: University of Wisconsin-Milwaukee, Center for Instructional and Professional Development.

O'Malley, R. (2002). SoTL reflections on efforts to find appropriate technology on pedagogy to stimulate student participation in the learning process. Models in our midst (pp. 41-47). Milwaukee, WI: University of Wisconsin-Milwaukee, Center for Instructional and Professional Development.

O'Meara, K. (2002). Uncovering the values in faculty evaluation of service as scholarship. Review of Higher Education, 2Q1), 57-80.

O'Reilley, M. R. (1993). The peaceable classroom. Portsmouth, NH: Boynton/CookHeinemann.

O'Reilley, M. R. (1998). Radical presence: Teaching as contemplative practice. Portsmouth, NH: Boynton/Cook-Heinemann.

O'Reilley, M. R. (2000). The barn at the end of the world: The apprenticeship of a Quaker, Buddhist shepherd. Minneapolis, MN: Milkweed.

Outcalt, C. (2000). Community college teaching: Toward collegiality and community. Community College Revieur, 28(2), 57-70.

Padilla, A. M. (1994). Ethnic minority scholars, research, and mentoring: Current and future issues. Educational Researcher, 23(4), 24-27.

Palmer, J. C., \& Vaughan, G. B. (1992). Fostering a climate for faculty scholarship at community colleges. Washington. DC: American Association of Community and Junior Colleges.

Palmer, P. J. (1983). To know as we are known: Education as a spiritual journey. San Francisco, CA: Harper. 
Palmer, P. J. (1991). The active life: Wisdom for creativity and caring. San Francisco, CA: Harper.

Palmer, P. J. (1997). The courage to teach: Exploring the inner landscape of a teacher's life. San Francisco, CA: Jossey-Bass.

Palmer, P. J. (2000). Let your life speak: Listening for the voice of vocation. San Francisco, CA: Jossey-Bass.

Parks, S. (1986). The critical years: Young adults and the search for meaning, faith, and commitment. San Francisco, CA: Harper.

Pascarella, E. T., \& Terenzini, P. T. (1991). How college affects students: Findings and insights from twenty years of research. San Francisco, CA: Jossey-Bass.

Patton, M. Q. (2002). Qualitative evaluation and research methods (3rd ed.). Thousand Oaks, CA: Sage.

Paul, R. W., Elder, L., \& Bartell, T. (1997). Califormia teacher preparation for instruction in critical thinking: Research findings and policy recommendations. Sacramento, CA: California Commission on Teacher Credentialing.

Pintrich, P. R., Marx, R. W., \& Boyle, R. A. (1993). Beyond cold conceptual change: The role of motivational beliefs and classroom contextual factors in the process of conceptual change. Review of Educational Research, 63(2), 167-199.

Pohland, P., \& Bova, B. (2000). Professional development as transformational learning. International Journal of Leadership in Education, 3(2), 137-150.

Poock, M. C. (2001). A model for integrating professional development in graduate education. College Student Journal, 35(3), 345-353. Retrieved May 9, 2004, from hetp://articles.findarticles.com/p/articles/mi_m0FCR/is_3_35/ai_80744646

Prawat, R. (1992, May). Teachers' belief about teaching and learning: A constructivist perspective. American Journal of Education, 100(3), 354-395.

Professional and Organizational Development Network in Higher Education. (2001). Membership directory and networking guide. Miami Beach, FL: Author.

Proust, M. (1948). La prisonniere. (J. O'Brien, Ed. \& Trans.). New York, NY: Columbia University Press. (Original work published 1924)

Ramsden, P. (1992). Learning to teach in higher education. London, England: Routledge.

Ratcliff, J. L. (1996). What is a curriculum and what should it be? In J. G. Gaff, J. L. Ratcliff, \& Associates (Eds.), Handbook of the undergraduate curriculum: $A$ comprehensive guide to purposes, structures, practices, and change (pp. 5-29). San Francisco, CA: Jossey-Bass. 
Rathburn, J. (2002). Using technology to enhance learning and understanding. In C. Schroeder \& A. Ciccone (Eds.), Models in our midst (pp. 49-58). Milwaukee, WI: University of Wisconsin-Milwaukee, Center for Instructional and Professional Development.

Rhem, J. (1995). Close Up Column: Going deep. National Teaching and Learning Forum, 5(1), 4.

Rhoads, R. A., \& Howard, J. (Eds.). (1998). Academic service learning: A pedagogy of action and reflection. San Francisco, CA: JosseyBass.

Rice, K., \& Pollack, S. (2000). Developing a critical pedagogy of service learning: Preparing self-reflective, culturally aware, and responsive community participants. In C. O'Grady (Ed.), Integrating service learning and multicultural education in colleges and universities (pp. 115-134). Mahwah, NJ: Lawrence Erlbaum.

Richardson, R., \& Moore, W. (1987). Faculty development and evaluation in Texas community colleges. Community/Junior College Quarterly, 11, 19-32.

Robertson, D. L. (1997). Transformative learning and transition theory: Toward developing the ability to facilitate insight. Journal on Excellence in College Teaching. $8(1), 105-125$.

Robertson, D. L. (1999). Professors' perspectives on their teaching: A new construct and developmental model. Innovative Higher Education, 23(4), 271-294.

Roueche, J. E., Roueche, S. D., \& Milliron, M. D. (1995). Strangers in their own land: Part-time faculty in American community colleges. Washington, DC: Community College Press.

Roueche, J. E., Roueche, S. D., \& Milliron, M. D. (1996a, Spring). Identifying the strangers: Exploring part-time faculty integration in American community colleges. Community College Review, 23(4), 33-48.

Roueche, J. E., Roueche, S. D., \& Milliron, M. D. (1996b, March). In the company of strangers: Addressing the utilization and integration of part-time faculty in American community colleges. Community College Journal of Research and Pracsice, 20(2), 105-117.

Rue, P. (1996). Administering successful service-learning programs. In B. Jacoby \& Associates (Eds.), Service-learning in higher education: Concepts and practices (pp. 246-275). San Francisco, CA: Jossey-Bass. 
Sandford, B., \& McCaslin, N. L. (2003, October). Assessment of professional development activities, instructional needs, and methods of delivery for part-time technical and occupational faculty in U.S. community colleges. Paper presented at the Midwest Research to Practice Conference in Adult, Continuing, and Community Education, Columbus, OH. Retrieved May 9, 2004, from htrp://www.alumni-osu.org/midwest/midwest\%20papers/Sandford\%20\&\%20McCaslin--Done.pdf

Sarko, L. (1964, October). The problem of teaching in community colleges. Journal of Higher Education, 35(7), 384-386.

Saunders, S. A., \& Ervin, L. (1984). Meeting the special advising needs of students. In R. B. Winston, T. K. Miller, S. C. Ender, T. J. Grites, \& Associates (Eds.), Developmental academic advising: Addressing students' educational, career, and personal needs (pp. 250-286). San Francisco, CA: Jossey-Bass.

Schonwetter, D. T., Sokal, L., Friesen, M., \& Taylor, K. L. (2002). Teaching philosophies reconsidered: A conceptual model for the development and evaluation of teaching philosophy statements. International Journal of Academic Development, $\pi(1), 83-97$.

Schroeder, C. (2001). Faculty change agents: Individual and organizational factors that enable or impede faculty involvement in organizational change (Doctoral dissertation, University of Wisconsin-Madison, 2001). Dissertation Abstracts Internationah No. 0262.

Schroeder, C., \& Ciccone, A. (Eds.). (2002). Models in our midst. Milwaukee, WI: University of Wisconsin-Milwaukee, Center for Instructional and Professional Development.

Schroeder, C., \& Ciccone, A. (Eds.). (2003). Learning more about learning. Milwaukee, WI: University of Wisconsin-Milwaukee, Center for Instructional and Professional Development.

Schuster, J. H. (1985, September). Faculty vitality: Observations from the field. New Directions for Higher Education: No. 51. (pp. 21-32).

Schuster, J. H. (1990). The need for fresh approaches to faculty renewal. In J. H. Schuster, D. W. Whecler, \& Associates (Eds.), Enhancing faculty careers: Strategies for development and renewal (pp. 3-19). San Francisco, CA: Jossey-Bass.

Schuster, J. H. (1995). Whither the faculty? The changing academic labor market. Educational Record, 7Q4), 28-33.

Schuster, J. H., Wheeler, D. W., \& Associares. (Eds.). (1990). Enhancing faculty careers: Strategies for development and renewal. San Francisco, CA: Jossey-Bass. 
Self, D. J., \& Baldwin, D. C., Jr. (1994). Moral reasoning in medicine. In J. R. Rest \& D. Narváez (Eds.), Moral development in the professions: Psychology and applied ethics (pp.147-162). Mahwah, NJ: Lawrence Erlbaum.

Self, D. J., Olivarez, M., \& Baldwin, D. C., Jr. (1994). Moral reasoning in veterinary medicine. In J. R. Rest \& D. Narváez (Eds.), Moral development in the professions: Psychology and applied ethics (pp. 163-171). Mahwah, NJ: Lawrence Erlbaum.

Senge, P., Kleiner, A., Roberts, C., Ross, R., Roth, G., \& Smith, B. (1999). The dance of change: The challenges to sustaining momentum in learning organizations. New York, NY: Currency Doubleday.

Senge, P. M. (1990). The fifth discipline: The art of practice of the learning organization. New York, NY: Currency Doubleday.

Shachtman, T. (1995). The inarticulate society: Eloquence and culture in America. New York, NY: Free Press.

Shulman, L. S. (1986). Those who understand: Knowledge growth in teaching. Educational Researcher, 15, 4-14.

Shulman, L. S. (1993, November/December). Teaching as community property: Putting an end to pedagogical solitude. Change, 25(6), 6-7.

Shulman, L. S. (1999, July/August). Taking learning seriously. Change, 31(4), 11-17.

Smith, P. (1990). Killing the spirit: Higher education in America. New York, NY: Viking.

Smith, S. J., Pedersen-Gallegos, L., \& Riegle-Crumb, C. (2002). The training, carecrs, and work of Ph.D. physical scientists: Not simply academic. American Journal of Physics, 70(11), 1081-1092.

Sokol, A., \& Cranton, P. (1998, Spring). Transforming, not training. Adult Learning, (3), 14-17.

Sorcinelli, M. D. (2002). Ten principles of good practice in creating and sustaining teaching and learning centers. In K. H. Gillespie, L. R. Hilsen, \& E. C. Wadsworth (Eds.), A guide to faculty development: Practical advice, examples, and resources. Bolton, MA: Anker.

Stanton, T., Giles, D., \& Cruz, N. (1999). Service-learning: A movement's pioneers reflect on its origins, practice and future. San Francisco, CA: Jossey-Bass.

Steinert, Y. (2000, January). Faculty development in the new millennium: Key challenges and future directions. Medical Teacher, 22, 44-50. 
Sternberg, R. J., \& Grigorenko, E. L. (2002). The theory of successful intelligence as a basis for instruction and assessment in higher education. In D. F. Halpern \& $\mathrm{M}$. D. Hakel (Eds.), New directions for teaching and learning: No. 89. Applying the science of learning to university teaching and beyond (pp. 45-54). San Francisco, CA: Jossey-Bass.

Stone, T. E. (1996). Developing instructional objectives, lesson plans, and syllabi. In V. Bianco-Mathis \& N. Chalofsky (Eds.), The adjunct faculty handbook (pp. 28-39). Thousand Oaks, CA: Sage.

Swail, W. S. (2002, July/August). Higher education and the new demographics: Questions for policy. Change, 34(4), 15-23.

Tagg, J. (2003). The learning paradigm college. Bolton, MA: Anker.

Tannen, D. (1998). The argument culture: Stopping America's war of words. New York, NY: Ballantine.

Taylor, E. W. (2000). Analyzing research on transformative learning theory. In J. Mezirow \& Associates (Eds.), Learning as transformation: Critical perspectives on a theory in progress. San Francisco, CA: Jossey-Bass.

Teaching Partners Lunch Discussion. (2000, October 13). Unpublished tape transcript.

Tiberius, R. G. (2002). A brief history of educational development: Implications for teachers and developers. In D. Lieberman \& C. Wehlburg (Eds.), To improve the academy: Vol. 20. Resources for faculty, instructional, and organizational development (pp. 20-37). Bolton, MA: Anker.

Tiberius, R. G., Sacklin, H. D., Janzen, K. R., \& Preece, M. (1993). Alliances for change: A procedure for improving teaching through conversations with learners and partnerships with colleagues. Journal of Staff. Program, and Organizational Development, 11(1), 11-22.

Tierney, W. G. (1987). Facts and constructs: Defining reality in higher education organizations. Review of Higher Education, 11(1), 61-73.

Tierney, W. G. (1997). Organizational socialization in higher education. Journal of Higher Education, 68(1), 1-16.

Tierney, W. G., \& Bensimon, E. M. (1996). Promotion and tenure: Community and socialization in academe. Albany, NY: State University of New York Press.

Tierney, W. G., \& Rhoads, R. A. (1993). Enhancing promotion, tenure and beyond: Faculty socialization as a cultural process (ASHE-ERIC Higher Education Report No. 6). Washington, DC: George Washington University. 
Trigwell, K., \& Prosser, M. (1996). Congruence between intention and strategy in university science teachers' approaches to teaching. Studies in Higher Education, $32,77-87$.

Trosset, C. (1998, September/October). Obstacles to open discussion and critical thinking: The Grinnell College study. Change, 30(5), 44-49.

Turner, C. S. V. (2002). Women of color in academe: Living with multiple marginality. Journal of Higher Education, 73(1), 74-93.

Turner, C. S. V., \& Myers, S. L., Jr. (2000). Faculty of color in academe: Bittersweet success. Needham Heights, MA: Allyn and Bacon.

Turner, C. S. V., \& Thompson, R. J. (1993). Socializing women doctoral students: Minority and majority experiences. Review of Higher Education, 16(3), 355-370.

University of the Sciences in Philadelphia. (2002). Tactical planning group report on creating a culture of student-centered learning and living. Philadelphia, PA: Author.

U.S. Department of Education, National Center for Education Statistics. (1998). Digest of education statistics. Washington, DC: Author.

van der Bogert, V., Brinko, K. T., Atkins, S. S., \& Arnold, E. L. (1990). Transformational faculty development: Integrating the feminine and the masculine. In $\mathrm{L}$. Hilsen (Ed.), To improve the academy: Vol. 9. Resources for student. faculty, and institutional development (pp. 89-98). Stillwater, OK: New Forums Press.

Van Horn, C. E. (1995). Enhancing the connection between higher education and the workplace: $A$ survey of employers. Denver, CO: State Higher Education Executive Officers and Education Commission of the States.

Walvoord, B. E., \& Anderson, V. J. (1998). Effective grading: A tool for learning and assessment. San Francisco, CA: Jossey-Bass.

Ward, K. (1998). Addressing academic culture: Service learning, organizations, and faculty work. In R. A. Rhoads \& J. Howard (Eds.), Academic service learning: $A$ pedagogy of action and reflection (pp. 73-80). San Francisco, CA: Jossey-Bass.

Warren, R., \& Plumb, E. (1999). Survey of distinguished teacher award schemes in higher education. Joumal of Further and Higher Education, 23(2), 245-255.

Waters, T., Marzano, R. J., \& McNulty, B. (2003). Balanced leadership: What 30 years of research tells us about she effect of leadership on student achievement. Aurora, $\mathrm{CO}$ : Mid-continent Research for Education and Learning.

Wehlburg, C. M. (2000, Fall). Respecting students and faculty: The need for "intrusive" assessment. The Department Chair, 11(2), 20-22. 
Wehlburg, C. M. (2002). More than a thermometer: Using assessment effectively. In G. S. Wheeler (Ed.), Teaching and learning in college: A resource for educators (4th ed., pp. 177-199). Elyria, OH: Info-Tec.

Weigert, K. (1998). Academic service learning: Its meaning and relevance. In R. A. Rhoads \& J. Howard (Eds.), Academic service learning: $A$ pedagogy of action and reflection (pp. 3-10). San Francisco, CA: Jossey-Bass.

Weimer, M. (2002). Learner-centered teaching: Five key changes to practice. San Francisco, CA: Jossey-Bass.

Wenger, E. (1998). Communities of practice: Learning, meaning and identity. New York, NY: Cambridge University Press.

Wenger, E., McDermotr, R., \& Snyder, W. M. (2002). Cultivating communities of practice: $A$ guide to managing knowledge. Boston, MA: Harvard Business School Press.

Wergin, J. F. (2003). Departments that work: Building and sustaining cultures of excellence in academic programs. Bolton, MA: Anker.

Westacott, B., \& Hegeman, C. (Eds.). (1996). Service learning in elder care: A resource manual. Albany, NY: Foundation for Long Term Care.

Wiggins, G. (1996, Winter). Embracing accountability. New Schools, New Communities, 12(2), 4-10.

Wilber, K. (1998). The marriage of sense and soul: Integrating science and religion. New York, NY: Random House.

Wilcox, S. (1997). Becoming a faculty developer. In P. Cranton (Ed.), New directions for adult and continuing education: No. 74. Transformative learning in action: Insights from practice (pp. 23-32). San Francisco, CA: Jossey-Bass.

Williams, J. (1986). A study of professional development practices of part-time instructors at selected League for Innovation community colleges. Los Angeles, CA: League for Innovation in the Community College.

Wright, D. L. (2000). Faculty development centers in research universities: A study of resources and programs. In M. Kaplan \& D. Lieberman (Eds.), To improve the academy: Vol. 18. Resources for faculty, instructionah, and organizational development (pp. 291-301). Bolton, MA: Anker.

Wunsch, M. A. (1994). New directions for mentoring: An organizational development perspective. In M. A. Wunsch, R. J. Menges, \& M. D. Svinicki (Eds.), New directions for teaching and learning: No. 57. Mentoring revisited: Making an impact on individuals and institutions (pp. 9-13). San Francisco, CA: Jossey-Bass. 
Wyles, B. (1998). Adjunct faculty in the community college: Realities and challenges. In D. W. Leslie (Ed.), New directions for higher education: No. 104. The growing use of part-time faculty: Understanding causes and effects (pp. 89-93). San Francisco, CA: Jossey-Bass.

Zemsky, R. (1989). Structure and coherence: Measuring the undergraduate curriculum. Washington, DC: Association of American Colleges.

Zimmerman, M. (1986). The evolution-creation controversy: Opinions from students in a "liberal" liberal arts college. Ohio Journal of Science, 86(4), 134-139.

Zlotkowski, E. (1996). Foreword. In L. Adler-Kassner, R. Crooks, \& A. Watters (Eds.), Composition-Writing the community: Concepts and models for servicelearning in composition (pp. v-vii). Washington, DC: American Association for Higher Education.

Zull, J. (2002). The art of changing the brain. Sterling, VA: Stylus. 